\title{
Article \\ Effect of Processing Parameters on Strength and Corrosion Resistance of Friction Stir-Welded AA6082
}

\author{
Aleksandra Laska $^{1}$ (D) , Marek Szkodo ${ }^{1}$ (D) Damian Koszelow $^{2}$ and Pasquale Cavaliere ${ }^{3, *(D)}$ \\ 1 Faculty of Mechanical Engineering and Ship Technology, Gdansk University of Technology, \\ Narutowicza 11/12, 80-233 Gdansk, Poland; aleksandra.laska@pg.edu.pl (A.L.); mszkodo@pg.edu.pl (M.S.) \\ 2 Faculty of Electronics, Telecommunications and Informatics, Gdansk University of Technology, \\ Narutowicza 11/12, 80-233 Gdansk, Poland; damian.koszelow@pg.edu.pl \\ 3 Department of Innovation Engineering, University of Salento, Via per Arnesano, 73100 Lecce, Italy \\ * Correspondence: pasquale.cavaliere@unisalento.it
}

Citation: Laska, A.; Szkodo, M.; Koszelow, D.; Cavaliere, P. Effect of Processing Parameters on Strength and Corrosion Resistance of Friction Stir-Welded AA6082. Metals 2022, 12, 192. https://doi.org/10.3390/ met12020192

Academic Editor: Byeong

Choon Goo

Received: 30 December 2021

Accepted: 19 January 2022

Published: 20 January 2022

Publisher's Note: MDPI stays neutral with regard to jurisdictional claims in published maps and institutional affiliations.

Copyright: (C) 2022 by the authors. Licensee MDPI, Basel, Switzerland. This article is an open access article distributed under the terms and conditions of the Creative Commons Attribution (CC BY) license (https:/ / creativecommons.org/licenses/by/ $4.0 /)$.

\begin{abstract}
The friction stir welding method is increasingly attracting interest in the railway sector due to its environmental friendliness, low cost, and ease of producing high-quality joints. Using aluminum alloys reduces the weight of structures, increasing their payload and reducing fuel consumption and running costs. The following paper presents studies on the microstructure, strength, and corrosion resistance of AA6082 aluminum alloy sheets joined via friction stir welding. The sheets were joined by employing two different traverse speeds (200 and $250 \mathrm{~mm} / \mathrm{min})$, two different rotational speeds (1000 and $1250 \mathrm{rpm})$, and two different tool tilt angles $\left(0^{\circ}\right.$ and $\left.2^{\circ}\right)$. It was observed that the use of the inclined tool provides finer microstructure in the nugget zone, higher value of microhardness, and better corrosion resistance, compared to the tilt angle equal to $0^{\circ}$. By increasing the value of revolutionary pitch, finer grains are observed in the nugget zone and the measured hardness is higher. It was also observed that the change in process parameters strongly influences the radius of the nugget zone and the potentiodynamic properties of the friction stir-welded material. The joints produced with the tool tilt angle equal to $2^{\circ}$, the tool traverse speed of $200 \mathrm{~mm} / \mathrm{min}$, and its rotational speed of $1250 \mathrm{rpm}$ revealed the highest hardness in the nugget zone (about $92 \%$ of the base material). Moreover, the finest grain size in the nugget with the average value of $9.8 \pm 1.5 \mu \mathrm{m}$ was found. The lowest corrosion current density equal to $16.029 \mu \mathrm{A} \mathrm{cm} \mathrm{cm}^{-2}$ was noted for the sample with the highest strength, which also provides its good corrosion resistance.
\end{abstract}

Keywords: friction stir welding; aluminum alloy; mechanical properties; corrosion; potentiodynamic behavior

\section{Introduction}

Friction stir welding (FSW) is a solid-state joining technique developed three decades ago at The Welding Institute of the United Kingdom [1]. During the process, a specially designed non-consumable tool, consisting of a pin and a shoulder rotates and moves along the weld line, while inserted between the contact line of two sheets to be joined. The friction generated by the contact of the rotating shoulder with the component surface generates intense heating always well below the melting point of the joined materials [2]. As the solid-state nature of the process is retained, the maximum temperature can approach up to 0.95 of the melting temperature $\mathrm{T}_{\mathrm{M}}$, depending on the process parameters, tool geometry, and material to be friction stir welded [3,4]. The plasticized material undergoes severe plastic deformations and its flow around the pin produces complex patterns from the advancing side, where the rotational direction and the welding direction are the same, to the retreating side, where the directions are opposite. Generally, FSW does not produce symmetric deformation with respect to the center line of the advancing tool. When a clockwise direction rotation is employed the less resistant area is the one on the advancing side of the tool [5]. 
Aluminum alloys, belonging to the $6 x x x$ series, are among the most employed materials for transportation, aerospace, and marine industries. They are characterized by silicon and magnesium elements added to induce intense second phases precipitation during thermo-mechanical treatments [6-8]. Owing to their stiffness, aluminum alloys can reduce the weight of structures by up to three times compared to steel structures. This aspect is crucial in transportation applications $[9,10]$. Using aluminum in train carriage bodies reduces the weight and energy amount that is needed to accelerate and deaccelerate them. Owing to this feature, the payload of vehicles can be increased, which leads to reduced fuel consumption and lower machine running costs [11]. According to The Welding Institute of the United Kingdom, there is an increasing number of railway sector companies applying the FSW method in the vehicle constructions. Many international companies leading the rail industry use the FSW method to create many series of trains and vehicles serving subway lines around the world [12].

6082 aluminum alloy has the highest strength of 6000 series in plate form [13-15]. It shows excellent machinability, good welding performances, and high corrosion resistance [16]. AA6082 alloy is widely used in the high-speed train industry, such as profiles and carriage components $[17,18]$. Conventional welding methods might lead to the formation of defects due to the change of state, such as poor solidification and porosity in the nugget zone. FSW allows to improve the weld quality and is widely used in joining AA6082 alloy [19-22]. Fewer scientific evidence are present in the literature on the effect of processing parameters on the electrochemical behavior of friction stir-welded AA6082 sheets. Gharavi et al. [23] investigated the electrochemical properties of AA6061-T6 alloy butt welds. It was revealed that the friction stir welds produced with the tool traverse speed of $60 \mathrm{~mm} / \mathrm{min}$, tool rotational speed equal to $1000 \mathrm{rpm}$, and tool tilt angle of $3^{\circ}$ showed lower electrochemical properties in $3.5(\mathrm{wt}) \% \mathrm{NaCl}$ solution compared to the base material. The intergranular corrosion type was dominant, with a small number of pits observed on the weld surface. On the other hand, Padovani et al. [24] noted that the pitting corrosion occurs on the friction stir welds and the base materials of AA2024 T351 and AA7449-T7951, but the weld region exhibited higher susceptibility to corrosion losses compared to the base material after the exposure to $0.1 \mathrm{M} \mathrm{NaCl}$ solution. In the studies of Ales et al. [25] the AA2024-T4 butt weld was produced with a tool traverse speed of $100 \mathrm{~mm} / \mathrm{min}$, tool rotational speed of $1000 \mathrm{rpm}$, and tool tilt angle $2^{\circ}$. It was noted that the most serious corrosion losses occurred in the weld nugget zone while exposed to 3.5 (wt) \% $\mathrm{NaCl}$ solution. In the studies, also the finest microstructure of the nugget zone was found, and a significant drop of the hardness in the thermo-mechanically affected zone was noted. No influence of the process parameters on the properties of the joints was investigated.

As general behavior, tool shoulder and pin geometries and types have a large influence on the microstructural and mechanical properties of FSWed joints [26]. In [27], Rambabu et al. developed a mathematical model for a friction stir-welded AA2219 aluminum alloy sample immersed in $3.5(\mathrm{wt}) \% \mathrm{NaCl}$ solution. The influence of process parameters on the electrochemical properties of the samples was investigated. It was revealed that the shape of the pin has also a crucial effect on the friction stir-welded structure and the corrosion properties. The best quality was attained with a hexagonal pin shape. For a hexagonal pin shape, the highest hardness was noted for AA6082-T6 friction stir welds, produced with different welding speed values by Patil et al. [28]. This is generally due to the fact that, by employing such a hexagonal shape, it is demonstrated that the material mixing is optimized during welding. This is mainly due to the phenomenon of reprecipitation because of the increased heating due to the complex geometry [29].

The purpose of this study was to analyze the effect of friction stir welding parameters such as tool traverse speed, tool rotational speed and its tilt angle on microstructure, hardness and electrochemical properties of AA6082 friction stir welds by employing a special designed hexagonal pin tool. 


\section{Materials and Methods}

Base material AA6082 aluminum alloy, solution heat-treated and artificially aged to T651 condition, was used for the above studies. The chemical composition of the chosen alloy was determined by the X-ray energy-dispersive spectrometer (EDS) (Edax Inc., Mahwah, NJ, USA) and is shown in Table 1.

Table 1. Chemical composition of AA6082.

\begin{tabular}{cccccccccc}
\hline & \multicolumn{1}{c}{ Chemical Composition $[w \mathbf{w} \%]$} \\
& Zn & Mg & Cr & Ti & Fe & Si & Cu & Mn & Al \\
\hline AA6082 & 0.20 & 1.03 & 0.25 & 0.10 & 0.50 & 0.90 & 0.10 & 0.42 & Balance \\
\hline
\end{tabular}

About 3-mm-thick plates were used to perform the friction stir welding process on a conventional milling machine (FU251, Friedrich Engels Kazanluk, Bulgaria). Figure 1 depicts the tool adopted for studies. The tool of $18 \mathrm{~mm}$ shoulder diameter, with the distance across flats of the hexagonal pin was equal to $6 \mathrm{~mm}$ and the pin length equal to $2.5 \mathrm{~mm}$ was used to produce the butt welds. The shoulder plunge depth was equal to $0.3 \mathrm{~mm}$. The hexagonal pin with grooves was made of 73MoV52 steel and the shoulder material was X210Cr12 steel. The measured hardness of the pin and the shoulder were equal to 58 and 61 HRC (Wilson Mechanical Instrument Co. Inc., New York, NY, USA), respectively. Based on an extensive literature review, published in [2], the following process parameters were selected for the studies: the FSW process was performed at two different travel speeds: 200 and $250 \mathrm{~mm} / \mathrm{min}$, two different rotational speeds: 1000 and $1250 \mathrm{rpm}$, and two different tilt angles: $0^{\circ}$ and $2^{\circ}$. The tilt direction of the tool was opposite to the direction of its traverse motion. The designation of the samples is shown in Table 2. The revolutionary pitch values, defined as the tool rotational speed divided by the tool traverse speed, are also presented in Table 2.
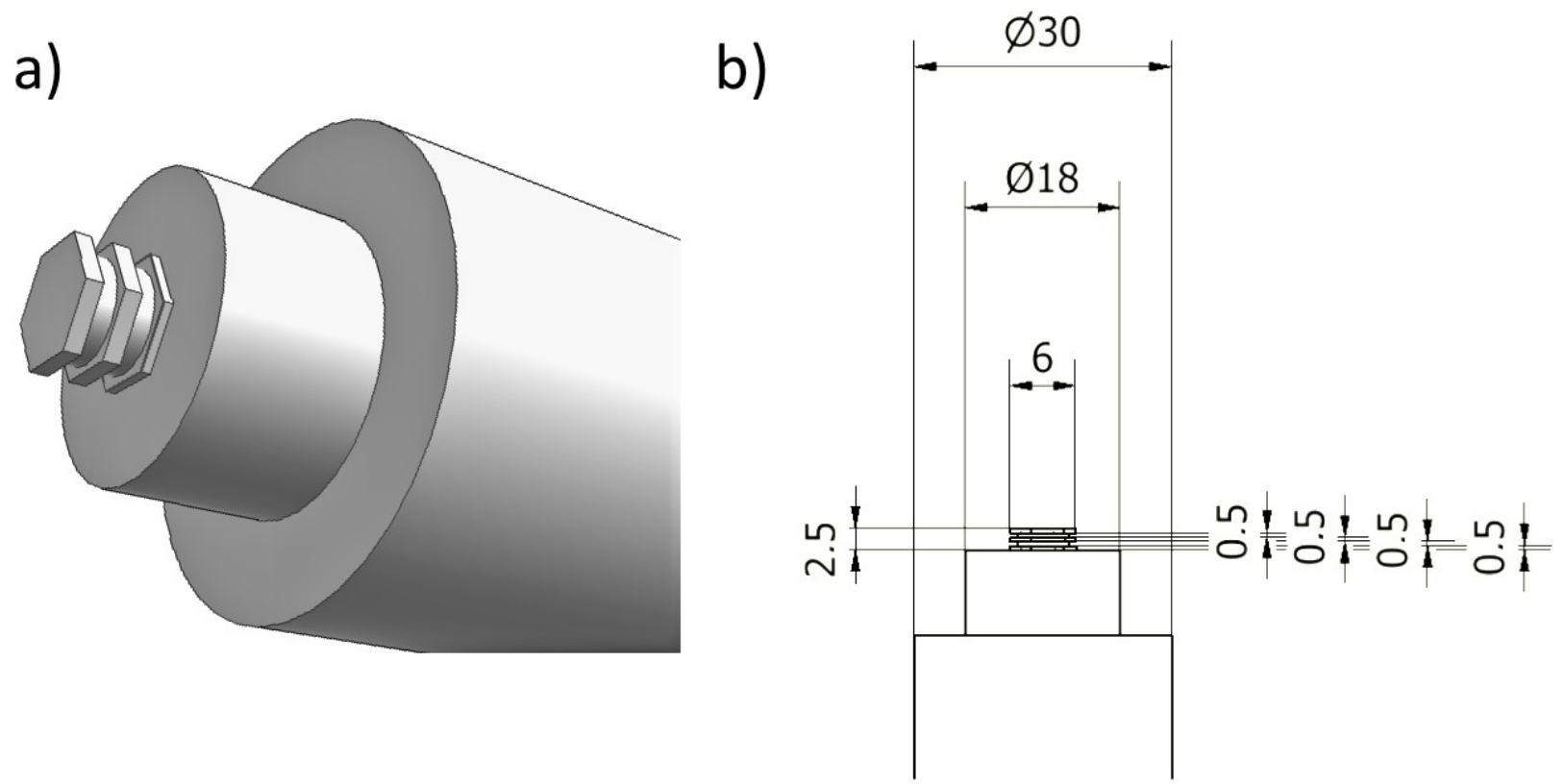

Figure 1. Schematic illustration of the geometry of the tool used for FSW of AA6082 (a) with its dimensions (b). 
Table 2. Designation of the samples, corresponding process parameters and revolutionary pitch values.

\begin{tabular}{ccccc}
\hline Sample & $\begin{array}{c}\text { Tool Rotational } \\
\text { Speed }[\mathbf{r p m}]\end{array}$ & $\begin{array}{c}\text { Tool Travel Speed } \\
{[\mathbf{m m} / \mathbf{m i n}]}\end{array}$ & $\begin{array}{c}\text { Tool Tilt } \\
\text { Angle }\left[{ }^{\circ}\right]\end{array}$ & $\begin{array}{c}\text { Revolutionary } \\
\text { Pitch [rot/min] }\end{array}$ \\
\hline FSW1 & 1000 & 200 & 0 & 5 \\
FSW2 & 1000 & 250 & 0 & 4 \\
FSW3 & 1250 & 200 & 0 & 6.25 \\
FSW4 & 1250 & 250 & 0 & 5 \\
FSW5 & 1000 & 200 & 2 & 5 \\
FSW6 & 1000 & 250 & 2 & 4 \\
FSW7 & 1250 & 200 & 2 & 6.25 \\
FSW8 & 1250 & 250 & 2 & 5 \\
\hline
\end{tabular}

To determine the microstructure of the produced friction stir welds, the samples were wet ground to the final gradation $\# 4000$ and polished with a $1 \mu \mathrm{m}$ diamond suspension. The microstructure was analyzed by employing Keller's etchant $\left(95 \mathrm{~mL} \mathrm{H}_{2} \mathrm{O}, 2.5 \mathrm{~mL} \mathrm{HNO}\right.$, $1.5 \mathrm{~mL} \mathrm{HCl}, 1 \mathrm{~mL} \mathrm{HF})$. For microstructure observations the double-staged etching in Weck's etchant was performed. At the first stage, the samples were etched in a solution of $2(\mathrm{wt}) \%$ $\mathrm{NaOH}$ for $1 \mathrm{~min}$. Then, the samples were immersed in a reagent containing $4 \mathrm{~g} \mathrm{KMnO}$, $1 \mathrm{~g} \mathrm{NaOH}$, and $100 \mathrm{~mL} \mathrm{H}_{2} \mathrm{O}$. The microstructure of the samples was observed by an optical microscope (BX51, OLYMPUS, Tokyo, Japan). To calculate the average grain size in the nugget zone, ten measurements were performed. The microhardness measurements were performed using a Vickers microhardness tester (Future-Tech FM-800, Tokyo, Japan) with the load of $2 \mathrm{~N}$. Figure 2 presents the locations of the microhardness measurements on the cross-sections of all the samples.

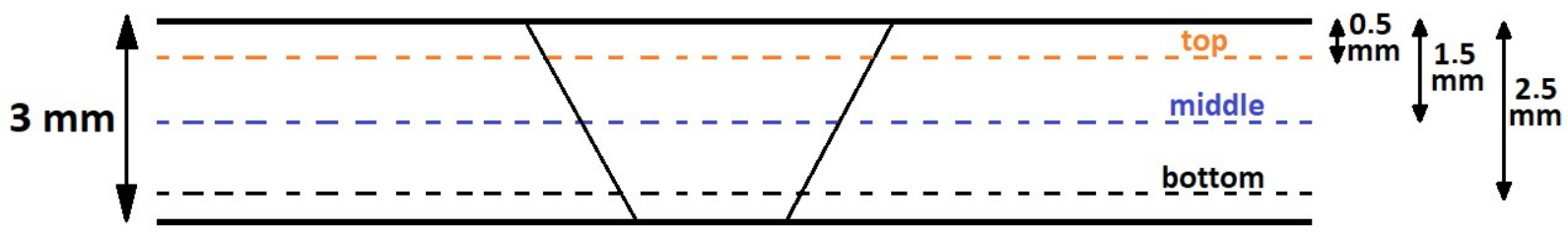

Figure 2. Hardness measurement locations on the cross-sections of the friction stir-welded samples.

Electrochemical measurements were performed according to the ASTM G5-94 "Standard reference test method for making potentiostatic and potentiodynamic anodic polarization measurements". Potentiostat/galvanostat (Atlas 0531, Atlas Sollich, Rębiechowo, Poland) was used for the tests in 3.5 (wt)\% $\mathrm{NaCl}(99.8 \%$ purity, CHEMPUR, Piekary Ślaskie, Poland) solution at the controlled temperature of $20^{\circ} \mathrm{C}$. Samples of the area of $1 \mathrm{~cm}^{2}$ taken from the nugget zone and AA6082 as received material were studied. A three-electrode system containing a platinum electrode as a counter electrode, a saturated calomel electrode as a reference, and an aluminum sample as a working electrode was used. The open circuit potential (OCP) within $60 \mathrm{~min}$ initiated the measurements. The potentiodynamic method was used to obtain the corrosion curves for the potential range $-2 /+1 \mathrm{~V}$ with a potential scan rate equal to $1 \mathrm{mV} / \mathrm{s}$. To determine the values of the corrosive potential $\left(\mathrm{E}_{\text {corr }}\right)$ and the corrosion current density ( $\left.\mathrm{i}_{\text {corr }}\right)$ the Tafel extrapolation method was adopted using AtlasLab (Atlas Sollich, Rẹbiechowo, Poland) software (ATLAS 0532 Electrochemical unit and Impedance Analyser). After the corrosion studies the surfaces of all the friction stir-welded samples and the base material were observed using a high resolution scanning electron microscope (SEM) (Phenom XL, Thermo Fisher Scientific, Breda, Netherlands) with a backscattered electron detector (BSE).

\section{Results and Discussion}

The results of visual testing of the produced friction stir welds are presented in Figure 3. The pictures present the area containing the exact nugget zone cutout location for electrochemical testing. It was observed that the top surfaces exhibit no serious imperfections 
like grooves or lack of bonding. A very little material outflow on the retreating side was noticed on samples FSW1-FSW4 (Figure 3a-d). No visible differences were detected on the top surface of all the produced friction stir welds.
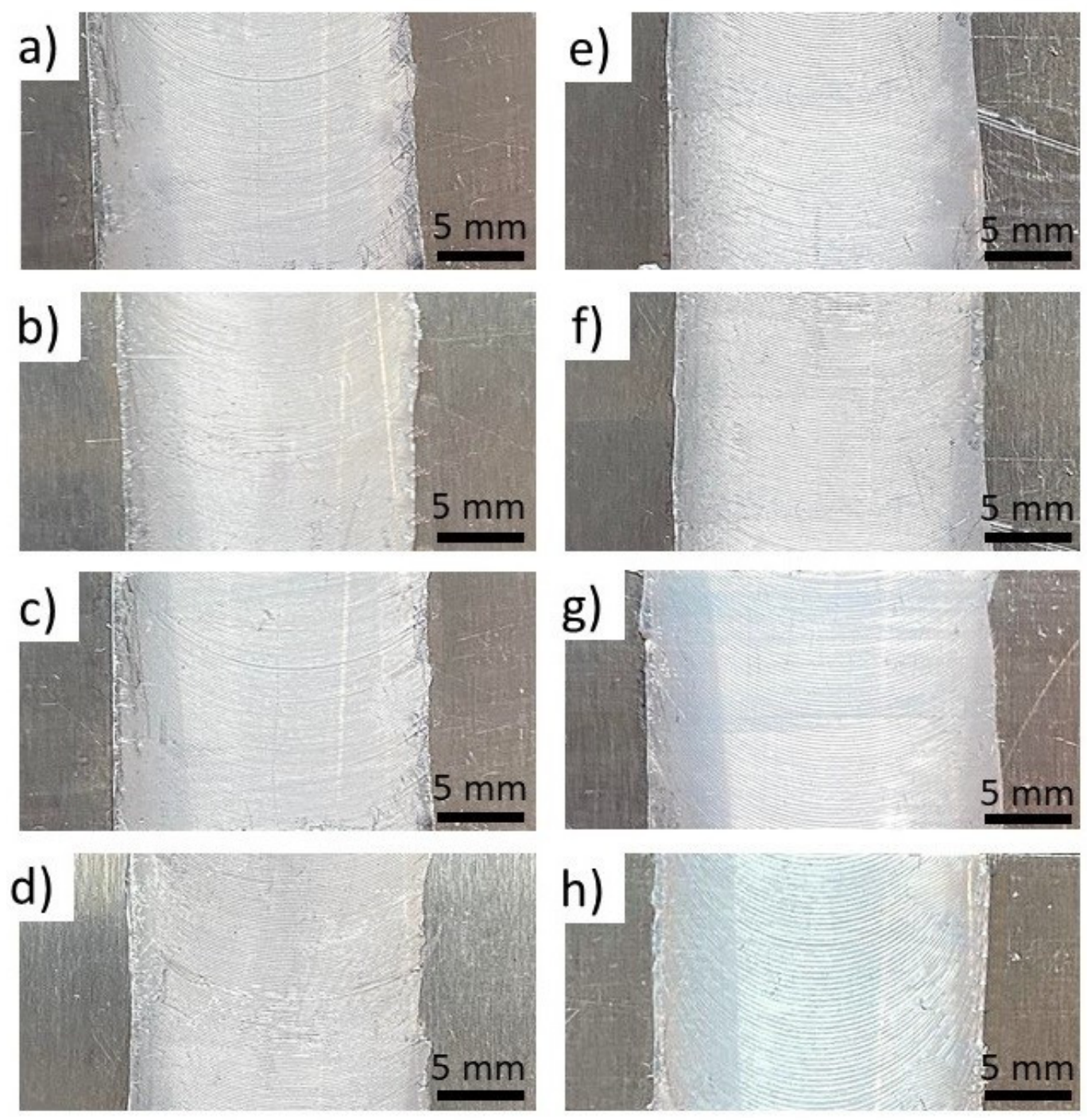

Figure 3. Top view of the friction stir welds surface-FSW1 (a), FSW2 (b), FSW3 (c), FSW4 (d), FSW5 (e), FSW6 (f), FSW7 (g) and FSW8 (h).

The macro and microstructure of one, representative friction stir weld (FSW7) is shown in Figure 4. The macroscopic evaluation (Figure 4a) allowed to observe the characteristic shape of the nugget zone, resulting from the movement of the pin between the sheets. The microscopic observations provided more information regarding the microstructure of the friction stir welds. Four characteristic zones for FSWs were recognized. Microstructure evolution during the process depends on the temperature and strain endured by welded material. High temperature changes, observed in the weld nugget zone (WN), as well as thermo-mechanically affected zone (TMAZ) and heat-affected zone (HAZ) result in characteristic microstructures. The weld nugget zone, where the plastic deformation and temperature are the highest is characterized by the finest structure, due to the dynamic recrystallization process. Figure $4 \mathrm{~b}$ presents the nugget zone microstructure of the FSW 7 sample. Process parameters such as traverse and rotational speed and tool tilt angle have a significant influence on the final microstructure, due to the different heat input. The average grain sizes in the WN zone for all samples tested are shown in Table 3. A thermo-mechanically affected zone (Figure $4 \mathrm{c}$ ) also experiences high temperature and 
mechanical deformation due to the movement of the pin, but no recrystallization is observed. The heat affected zone (Figure $4 \mathrm{~d}$ ) is only affected by thermal evolution, and with increasing the distance from the nugget zone, the base metal (BM) is retrieved (Figure 4e). In the base metal the observed elongated grains are the result of the sheet preparation process by rolling.
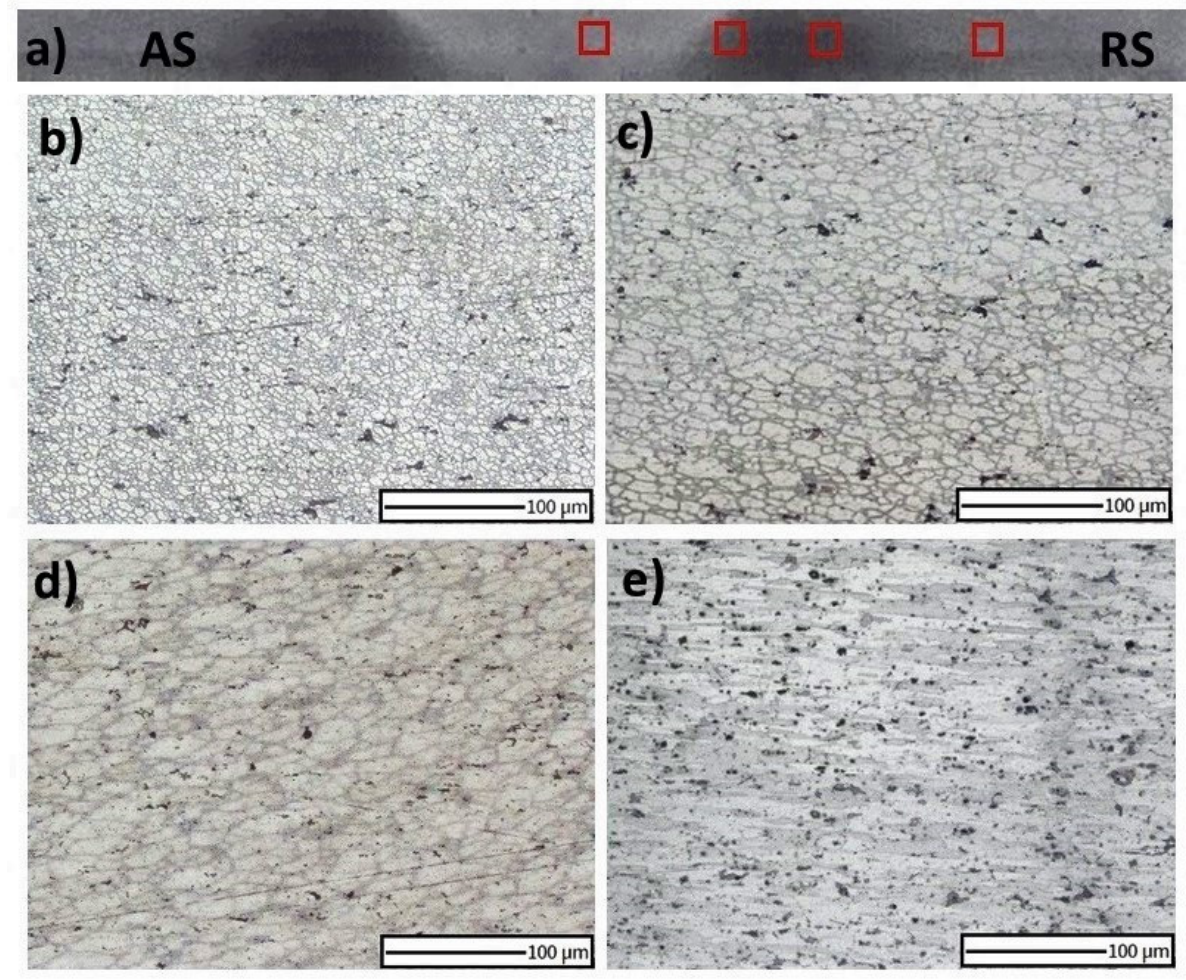

Figure 4. Macrostructure of FSW7 sample with the locations of microscopic observations (a) and its microstructures observed in the nugget zone (b), thermo-mechanically affected zone (c), heat-affected zone (d), and the microstructure of the base metal (e).

Table 3. Grain size in the nugget zone of all the produced friction stir welds.

\begin{tabular}{|c|c|c|c|c|c|c|c|c|}
\hline & FSW1 & FSW2 & FSW3 & FSW4 & FSW5 & FSW6 & FSW7 & FSW8 \\
\hline $\begin{array}{c}\text { Grain Size in the Weld } \\
\text { Nugget }[\mu \mathrm{m}]\end{array}$ & $13.5 \pm 2.1$ & $17.3 \pm 1.5$ & $12.8 \pm 1.5$ & $14.9 \pm 1.1$ & $10.3 \pm 1.8$ & $15.9 \pm 2.0$ & $9.8 \pm 1.5$ & $12.7 \pm 1.2$ \\
\hline
\end{tabular}

Figure 5 presents the relationship between the average grain size in the nugget zone of all the tested samples and the revolutionary pitch. It can be clearly observed that with increasing the revolutionary pitch, the average grain size in the nugget zone is decreased, for both applied tool tilt angles. The increase of the revolutionary pitch results in the increased heat input, which provides finer microstructure in such friction stir welds. Moreover, the use of an inclined tool influences the microstructure of the nugget zone. In the case of the welds produced with the tool tilt angle equal to $2^{\circ}$, the average grain size was lower than for the samples produced with non-tilted tool, for all the revolutionary pitch values. There are plenty of papers considering the heat input in the context of the inclination of the tool during the FSW process. Dialami et al. [30] studied the effect of the tool tilt angle on the heat generation and the material flow. It was assumed that an inclined tool increases stresses and the temperature during the process as well as strengthens the material stirring and facilitates the material flow behind the tool. Krishna et al. [31] observed that the heat input during the FSW process is not a uniform function of the tool tilt angle, but in general inclined function provides higher heat input and better plasticizing of the material to be 
welded. Analysis of Meshram et al. [32] shows that the tool tilt angle of $2^{\circ}$ provides the highest temperature of both advancing and retreating sides of the friction stir weld and thus proper plasticizing, mixing, and recrystallization are achieved.

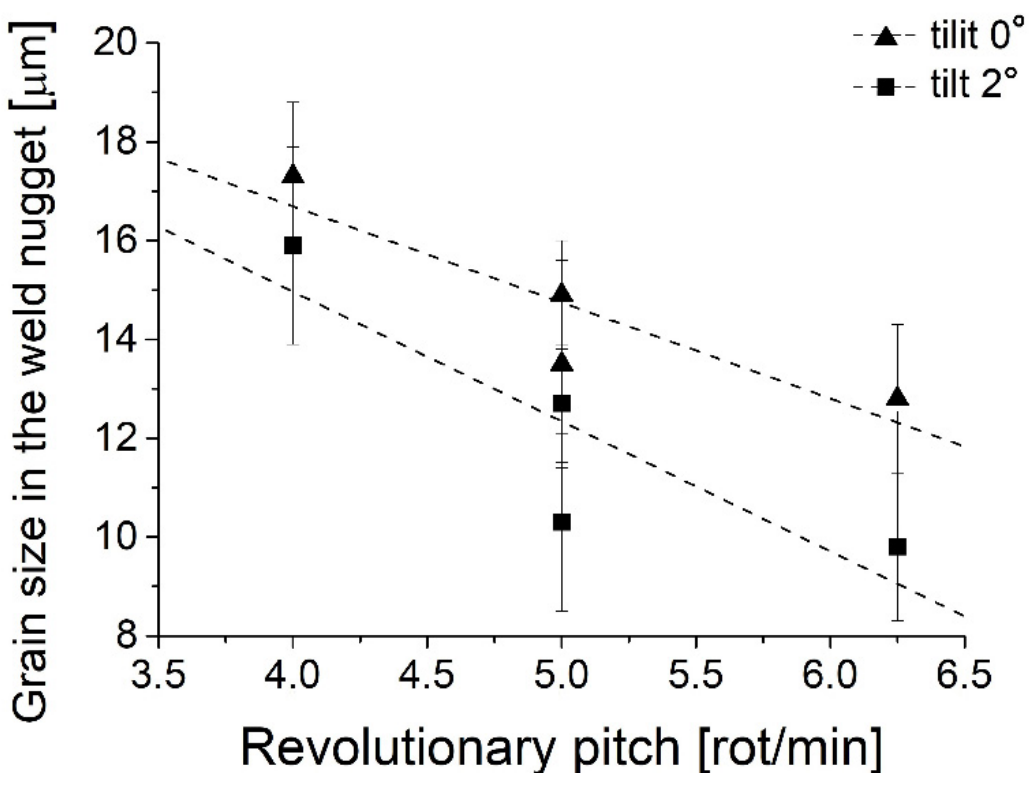

Figure 5. Average grain size in the nugget zone as a function of revolutionary pitch.

Figure 6 presents the Vickers microhardness profiles measured in different locations on the cross-sections of the friction stir welds. The microhardness of the base material was about $100 \mathrm{HV}$. Friction stir welding of precipitation hard-enable alloys, among them AA6082 aluminum alloy, results in the inhomogeneous hardness distribution leading to the formation of a softened area. The dissolution of the strengthening particles in the aluminum matrix and the decrease of the dislocation density causes the decrease of the hardness in the thermo-mechanically affected zone (TMAZ) and heat-affected zone (HAZ) [33-35]. In all the cases, the minimum hardness was observed in the heat-affected zone, while in the nugget zone a recovered hardness was noted. Due to the fine microstructure of the nugget zone, the increase in the hardness can be explained by the Hall-Petch relationship, which indicates the increase of the hardness as the grain size decreases [36]. The Hall-Petch equation can be expressed as:

$$
\sigma=\sigma_{0}+\mathrm{kd}^{-1 / 2}
$$

where $\sigma$ is the yield stress, $\sigma_{0}$ is the resistance to the dislocation motion in the grain interior, $\mathrm{k}$ is a measure of the local stress needed to initiate plastic flow at grain boundaries, and $\mathrm{d}$ is a grain size [37]. In the case of the hardness, the Equation (1) can be presented as:

$$
\mathrm{H}=\mathrm{H}_{0}+\mathrm{k}^{\prime} \mathrm{d}^{-1 / 2}
$$

where $\mathrm{H}$ is the hardness of the material, $\mathrm{H}_{0}$ and $\mathrm{k}^{\prime}$ are empirical constants [38]. The highest hardness of the nugget zone of about $92 \mathrm{HV}$ was noted for FSW7 samples. Moreover, the smallest grain size was observed for this sample, which is in agreement with the Hall-Petch relationship. 
a)

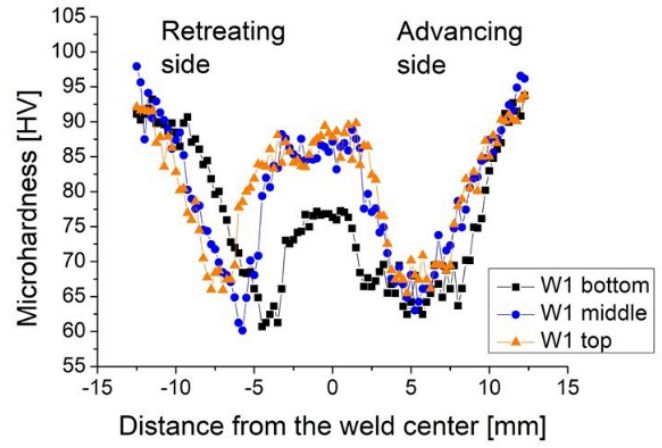

c)

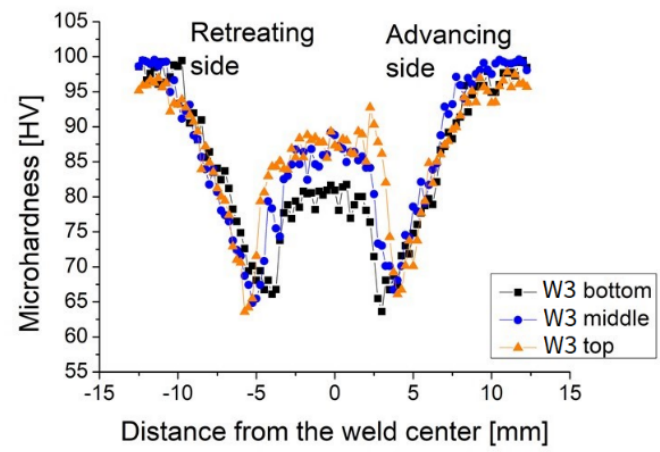

e)

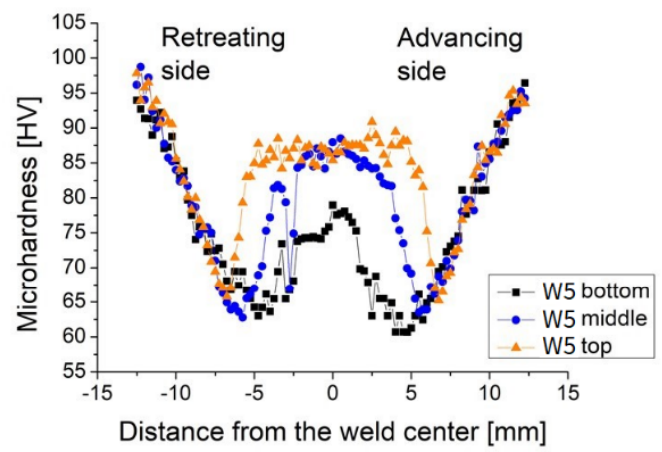

g)

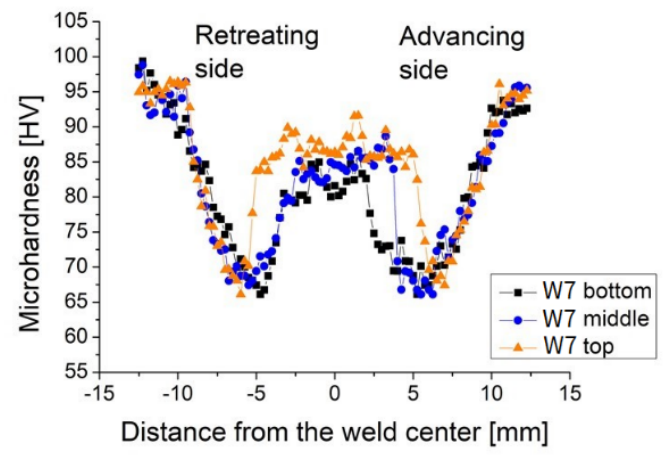

b)

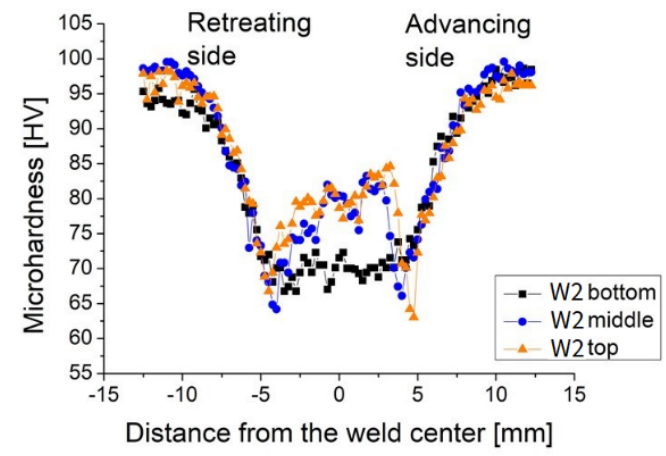

d)

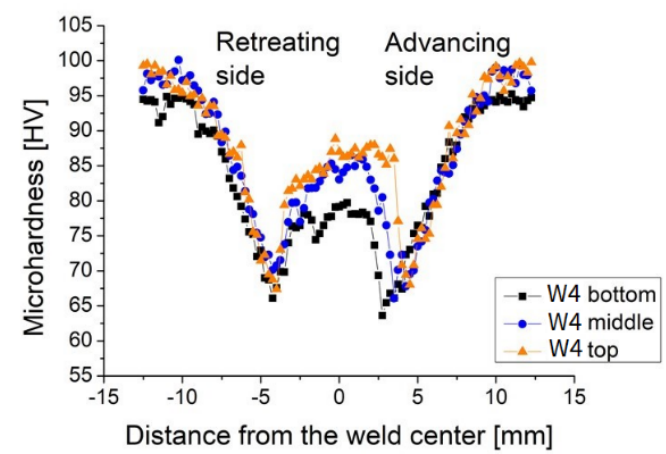

f)

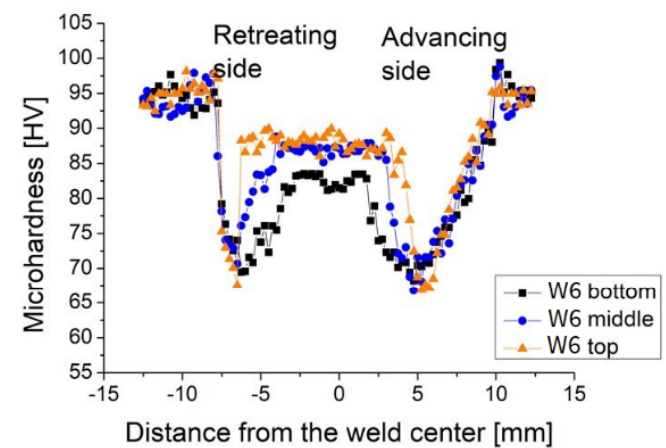

h)

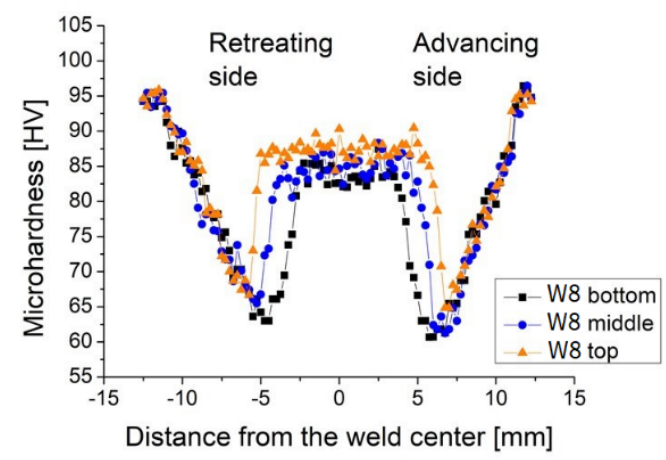

Figure 6. Microhardness profiles of the studied joints in the top, middle and bottom of the crosssections-FSW1 (a), FSW2 (b), FSW3 (c), FSW4 (d), FSW5 (e), FSW6 (f), FSW7 (g), FSW8 (h). 
The characteristic for the cross-sections of FSW joints hardness distribution is often reported in the case of aluminum alloys [39-44].

The summary of the main observations regarding the hardness profiles behavior is shown in Figure 7. It presents the correlation of the maximum hardness observed in the cross-sections of the nugget zone and the revolutionary pitch for the friction stir welds produced with the tool tilt angle of $0^{\circ}$ (a) and $2^{\circ}(\mathrm{b})$. In the case of $0^{\circ}$ tool tilt angle, the observed values of hardness were lower than the ones observed in the case of the samples FSW5-FSW8. Clearly, in all the cases the lowest values were noted in the bottom of all the friction stir welds, while the highest were observed in the top of the samples. The top of the friction stir welds experienced the most significant heating due to the contact with the tool shoulder and the frictional heating, resulting in the finest microstructure and the highest microhardness. Among all the welds, the maximum hardness, reaching approximately $92 \%$ of the base material, was observed for the samples with the revolutionary pitch value equal to 6.25 , for both applied the tool tilt angle values. As the revolutionary pitch increases, the heat input and the temperature during the process also increase. It can allow observing the most effective dynamic recrystallization. It can be also observed that for the samples produced with the highest revolutionary pitch the finest microstructure of the nugget zone was found. By decreasing the revolutionary pitch, the improper plastic flow might be observed and not sufficient dynamic recrystallization process can be noted. However, for further increase of the revolutionary pitch, the mixed material can be extremely softened and subjected to the grain growth, which would result in the significant decrease of the hardness in the nugget zone [45].

a)

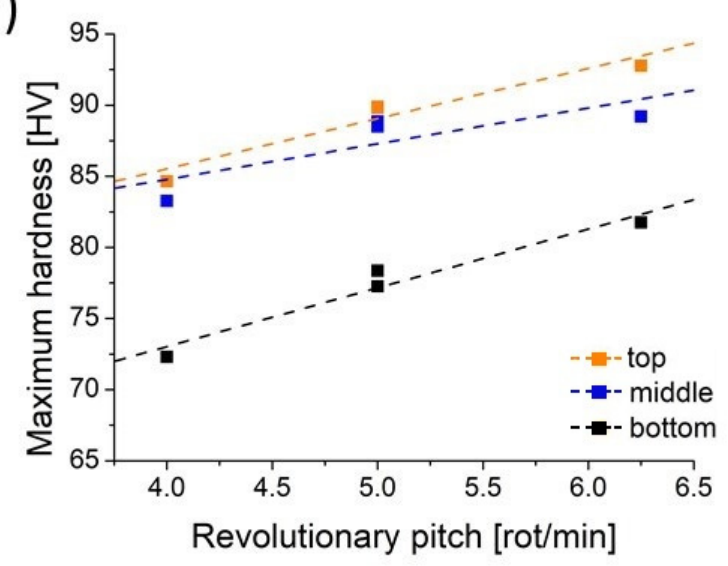

b)

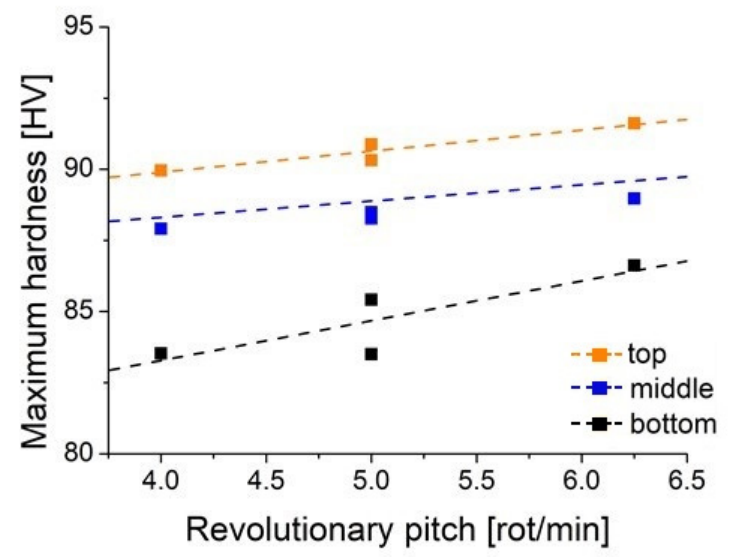

Figure 7. Maximum hardness of the nugget zone as a function of the revolutionary pitch-relationship for the friction stir welds produced with the tilt angle $0^{\circ}(\mathbf{a})$ and $2^{\circ}(\mathbf{b})$.

The radius of the nugget zone in the exact locations of the cross-sections of the friction stir welds as a function of the revolutionary pitch is presented in Figure 8. It can be clearly seen that in all the cases the highest values were observed in the top of the samples and the lowest in the bottom, which reflects the characteristic shape of the weld nugget [46-48]. It can be observed that with an increase of the revolutionary pitch, also the radius of the nugget zone increases. It is also attributed to the increase of the heat input during the process, as the revolutionary pitch is higher. In this case, the zone interested by the continuous dynamic recrystallization increases in dimensions and consequently the measured radius increases showing a larger zone of increased hardness with respect to TMAZ and HAZ. 
a)

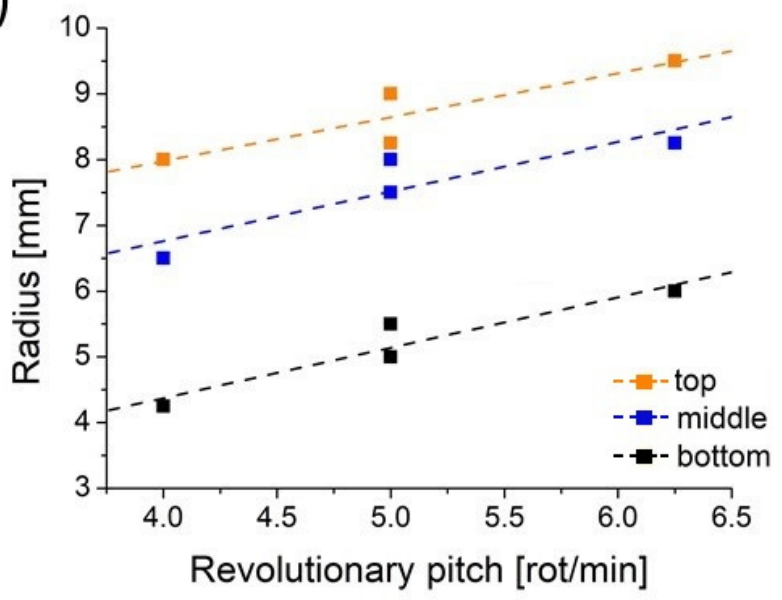

b)

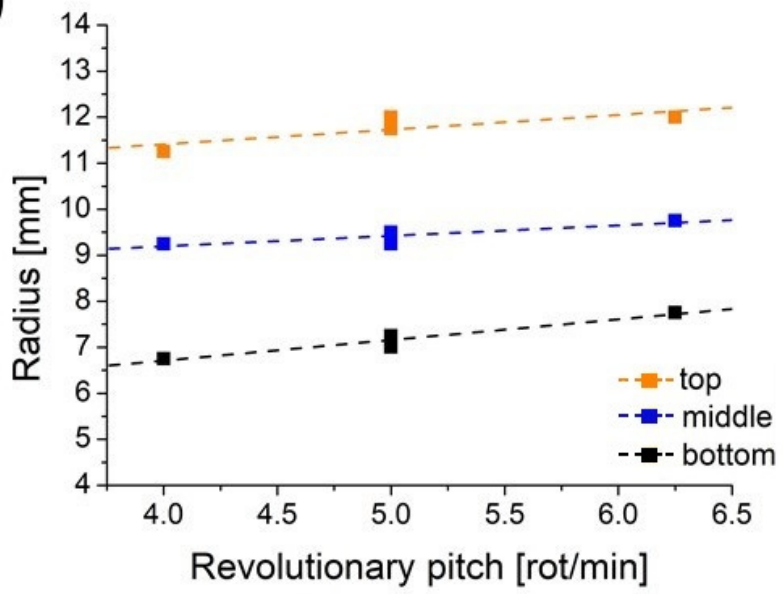

Figure 8. Radius of the nugget zone as a function of revolutionary pitch-relationship for the friction stir welds produced with the tilt angle $0^{\circ}(\mathbf{a})$ and $2^{\circ}(\mathbf{b})$.

Figure 9 presents the radius of the weld nugget in the function of the distance from the top of the friction stir weld for the samples with the revolutionary pitch equal to 4-FSW2 and FSW6 (for the tilt angle $0^{\circ}$ and $2^{\circ}$, respectively) (a), and for the samples FSW3 and FSW7 (for the tilt angle $0^{\circ}$ and $2^{\circ}$ ) -for the revolutionary pitch equal to 6.25 (b). These relationships clearly indicate that the use of an inclined tool increases the weld nugget zone for the entire cross-section of the specimen for both revolutionary pitch values analyzed. The same relationship was also observed for samples for which the revolutionary pitch value was 5 . It can also be clearly noted that the radius of the weld nugget decreases with the increase of the distance from the top surface, which reflects the shape of the weld nugget.

a)

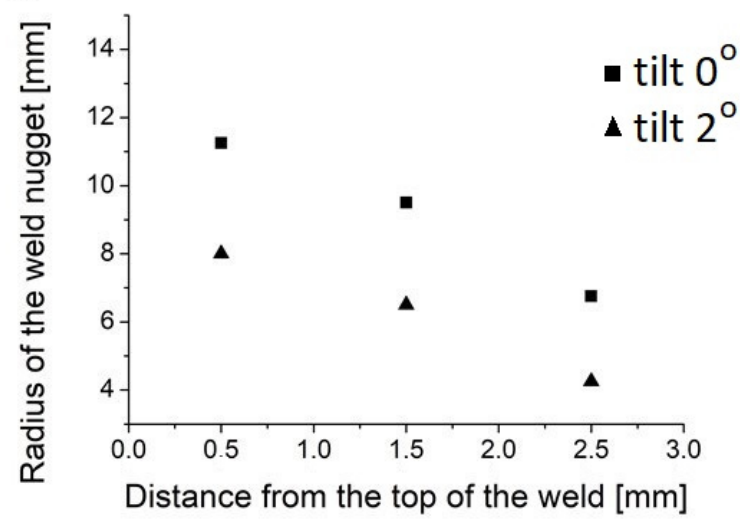

b)

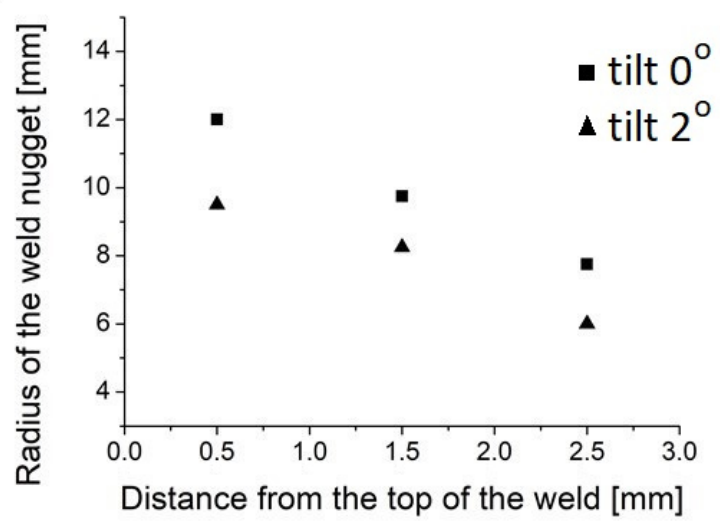

Figure 9. Radius of the weld nugget as a function of the distance from the top of the friction stir welds for the samples with the revolutionary pitch of 4 (a) and 6.25 (b).

Potentiodynamic studies are one of the basic tests to determine the properties of the produced friction stir welds. Their resistance to corrosion is of crucial importance not only in structures intended for marine vehicles, since even small corrosion losses caused by the influence of the environment may influence a significant decrease of the material strength. The potentiodynamic studies were initiated with the open circuit potential (OCP) measurements for $60 \mathrm{~min}$. After the stability of OCP was achieved, all the samples exhibited similar values and further potentiodynamic studies were performed. Based on the Tafel extrapolation method on the obtained potentiodynamic curves, the corrosive potential 
$\left(\mathrm{E}_{\mathrm{corr}}\right)$ and the corrosion current density $\left(\mathrm{i}_{\text {corr }}\right)$ values were collected. Table 4 contains the OCP, $\mathrm{E}_{\text {corr }}$, and $\mathrm{i}_{\text {corr }}$ values for all the tested samples.

Table 4. Open circuit potential (OCP), corrosion potential ( $\left.E_{\text {corr }}\right)$, and current density $\left(i_{\text {corr }}\right)$ for the produced samples.

\begin{tabular}{cccccccccc}
\hline & FSW1 & FSW2 & FSW3 & FSW4 & FSW5 & FSW6 & FSW7 & FSW8 & AA6082 \\
\hline \multirow{2}{*}{ OCP [V] } & -0.713 & -0.712 & -0.724 & -0.714 & -0.710 & -0.712 & -0.691 & -0.709 & -0.716 \\
& \pm 0.036 & \pm 0.036 & \pm 0.036 & \pm 0.036 & \pm 0.035 & \pm 0.036 & \pm 0.035 & \pm 0.035 & \pm 0.036 \\
$\mathrm{E}_{\text {corr }}[\mathrm{V}]$ & -0.682 & -0.680 & -0.684 & -0.676 & -0.654 & -0.648 & -0.649 & -0.659 & -0.686 \\
& \pm 0.034 & \pm 0.034 & \pm 0.034 & \pm 0.034 & \pm 0.033 & \pm 0.032 & \pm 0.032 & \pm 0.033 & \pm 0.034 \\
$\mathrm{i}_{\text {corr }}\left[\mu \mathrm{A} \cdot \mathrm{cm}^{-2}\right]$ & 22.898 & 23.907 & 17.303 & 20.809 & 19.208 & 19.128 & 16.029 & 18.895 & 42.564 \\
& \pm 1.145 & \pm 1.195 & \pm 0.865 & \pm 1.040 & \pm 0.960 & \pm 0.956 & \pm 0.801 & \pm 0.945 & \pm 2.128 \\
\hline
\end{tabular}

It can be observed that the corrosion potential shifts from the minimum of $-0.686 \mathrm{~V}$ for AA6082 sample to the maximum of $-0.648 \mathrm{~V}$ for FSW6 sample. It should be noted that an increase in corrosion potential occurred for all welded samples, with the group of samples joined at tool tilt angle $0^{\circ}$ (FSW1-FSW4) recording a smaller shift value. The FSW5-FSW8 specimens produced at a tool tilt angle of $2^{\circ}$ showed the greatest shift in corrosion potential toward positive values. The movement to more positive values indicates that the corrosion resistance of the friction stir-welded samples was improved. The highest corrosion current density, which means the lowest corrosion resistance, was observed on AA6082 base metal sample and the value was equal to $42.564 \mu \mathrm{A} \mathrm{cm}{ }^{-2}$. Almost two times lower values of $\mathrm{i}_{\text {corr }}$ were observed in the case of all the friction stir-welded samples, with the lowest value of $16.029 \mu \mathrm{A} \mathrm{cm}{ }^{-2}$ for FSW7 sample. Improvement of the corrosion resistance due to the FSW process was also observed by Qin et al. [49]. The 2A14-T6 aluminum alloy friction stir welds after electrochemical measurements in ex-foliation corrosion solution performed greatly improved corrosion resistance. Zucchi et al. [50] studied the pitting and stress corrosion cracking resistance of FSW AA5083 joints in $3.5 \% \mathrm{NaCl}+0.3 \mathrm{~g} / \mathrm{L}$ $\mathrm{H}_{2} \mathrm{O}_{2}$ and in ex-foliation solutions. In both cases, it was revealed that friction stir welds performed higher pitting and exfoliation corrosion resistance in comparison to the base material. The electrochemical studies on AA7022 FSW joints in $\mathrm{Na}_{2} \mathrm{SO}_{4}+$ dilute $\mathrm{H}_{2} \mathrm{SO}_{4}$ solution were performed by Wang et al. [51]. It was noted that the corrosion process in the base material was far greater than in the case of the friction stir welds under different process parameters. Monetta et al. [52] studied the corrosion resistance of AA6056 friction stir welds during the natural exposure in $3.5(\mathrm{wt}) \% \mathrm{NaCl}$ solution. It was revealed that the corrosion properties are strongly dependent on the process parameters. For relatively high welding speed, the pitting attack is more diffused and the pits penetration is less severe in the case of the nugget zone. For the FSW joints produced with lower welding speed the opposite observations were noted. The corrosion process was more pronounced within the nugget zone in comparison with the base material AA6056. In the studies of Padovani et al. [24] it was reported that FSW of AA2024 and AA7449 displayed greater susceptibility to pitting corrosion in the weld area after exposure to $0.1 \mathrm{M} \mathrm{NaCl}$ solution.

Figure 10a presents the potentiodynamic polarization curves for all the tested samples, while Figure 10b depicts the potentiodynamic polarization curves for the base material, FSW3 and FSW7, representing the friction stir welds with the lowest corrosion current density for the groups of the friction stir welds produced with the tilt angle of $0^{\circ}$ and $2^{\circ}$, respectively. 

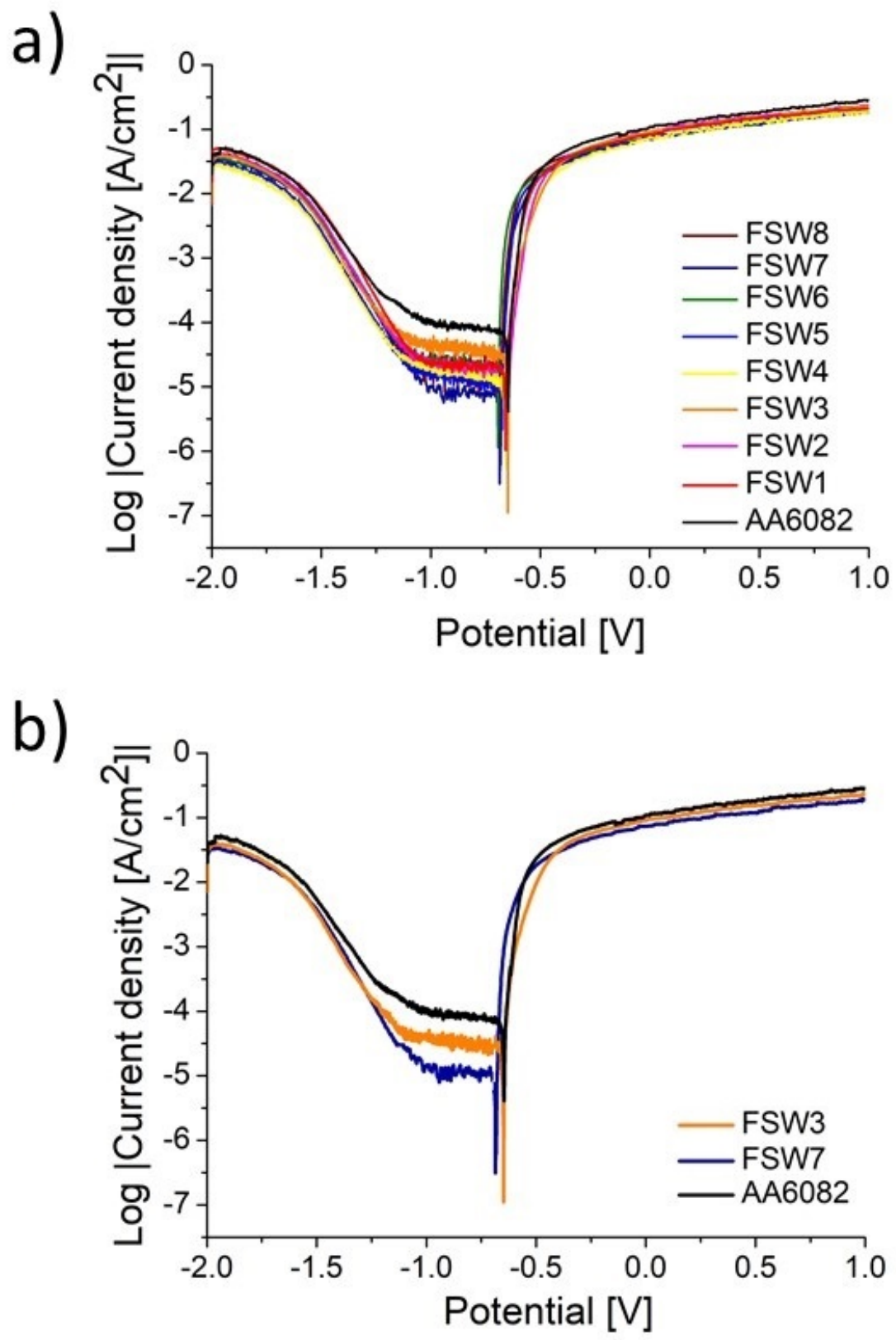

Figure 10. Potentiodynamic polarization curves for all the tested samples (a) and for AA6082 aluminum alloy, the FSW3 and FSW7 samples (b).

It was observed that, in general, the friction stir welds produced with the tool tilt angle of $0^{\circ}$ (FSW1-FSW4) exhibited higher $i_{\text {corr }}$ values compared to the welds produced with the same tool traverse speed and tool rotational speed, but with a tilt angle equal to $2^{\circ}$. These observations can be noted from the relationship of the corrosion current resistance as a function of revolutionary pitch presented in Figure 11. The trend line for the samples produced with the tilt angle of $0^{\circ}$ remains above the trend line for the friction stir welds produced with the tilt angle equal to $2^{\circ}$. It can be also observed that with an increase of revolutionary pitch, the corrosion current density decreases, and the corrosion resistance increases. The corrosion susceptibility of the studied samples is highly influenced by their microstructure. Ralston et al. [53] reported that in a neutral $\mathrm{NaCl}$ environment, the corrosion rate has a tendency to decrease with a reduction of a grain size of pure aluminum. It was suggested that the fine grain microstructure might have more reactive surface to the formation of the protective oxide layer. Moreover, in the studies of Song et al. [54] it was revealed that by providing finer grained structure, the pitting 
resistance of pure $\mathrm{Al}$ is increased, which is attributed to a denser oxide film on the surface of the samples. It should be also noted that FSW process changes not only the microstructure of the friction stir welds, but also has an influence on residual stresses and precipitation distribution, which may have an impact on electrochemical response as well.

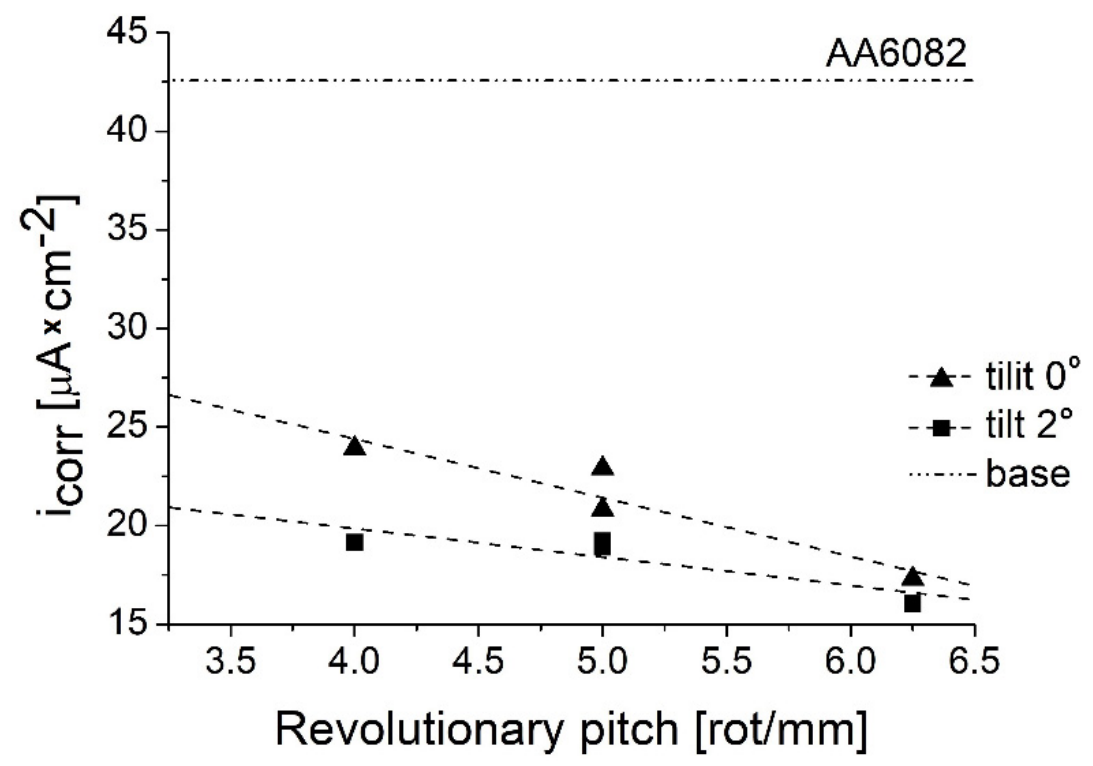

Figure 11. The relationship between corrosion current density and revolutionary pitch for all the tested samples.

Figure 12 presents the surfaces of the selected samples-FSW3, FSW7, and the base material AA6082. It can be observed that the base material (Figure 12c), thermally and mechanically unaffected during the movement of the tool exhibits the most serious corrosion losses on the surface. In Figure 12a,b, the characteristic shape of the top surface of the weld nugget is visible. A stepped structure is an effect of simultaneous rotation and traverse movement of a tool. It is observed that more significant corrosion losses are located on the top zone of the stepped surface. It can be explained by the corrosion propagation location at the edges of this structure. The passive layer at this location experiences a triaxial stress state, thus facilitating its delamination and corrosion propagation. A significant surface porosity can be observed on the surface of FSW3 sample. SEM images indicate that the lowest corrosion degradation can be observed on the sample FSW7, produced with a tool tilt angle of 2 and with the revolutionary pitch equal to 6.25. Although microscopic observations do not allow quantification of the amount of corrosion loss, a significantly higher degradation of the AA6082 base material was observed compared to all friction stir welds produced. Furthermore, it was noted that the samples produced at the tilt angle of $2^{\circ}$ (FSW5-FSW8) exhibited less intense material degradation, which agrees with the results of the electrochemical tests where these samples were characterized by lower corrosion current density values. 

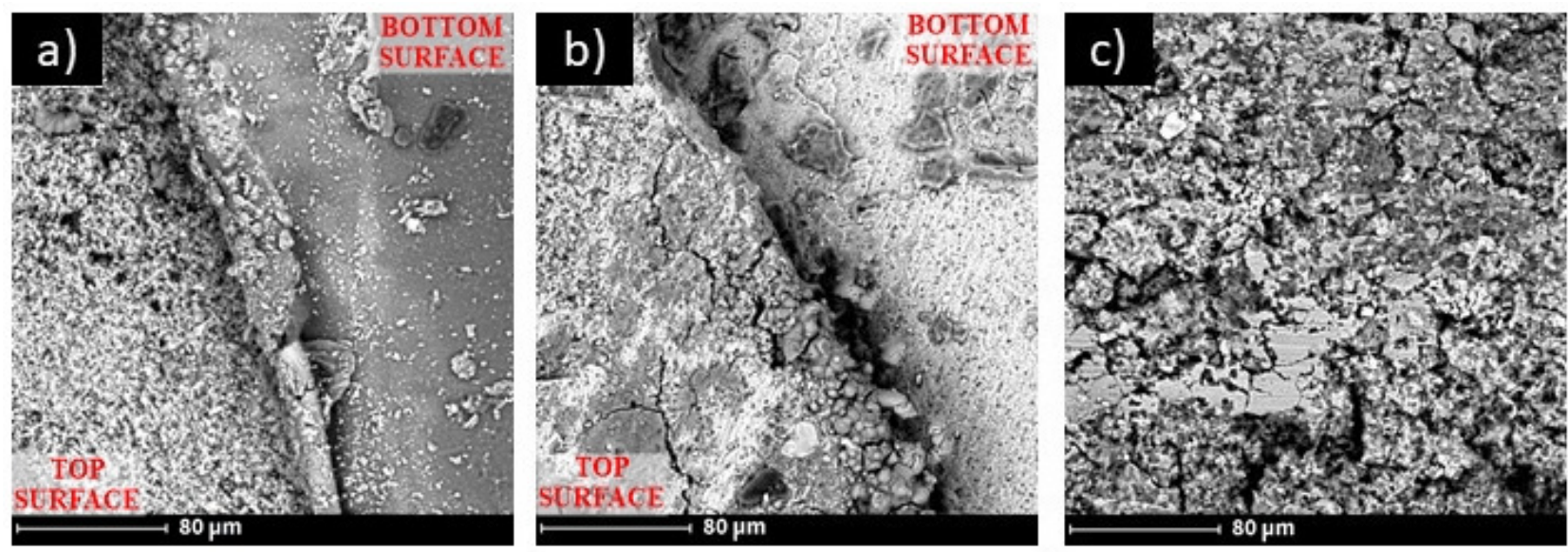

Figure 12. SEM images of the surface of the weld nugget of FSW3 (a), FSW7 (b) and AA6082 base material (c).

\section{Conclusions}

The above studies were conducted to investigate the microstructure, hardness, and electrochemical properties of friction stir-welded AA6082. For this purpose, two different rotational speeds (1000 and $1250 \mathrm{rpm}$ ), two different traverse speeds (200 and $250 \mathrm{~mm} / \mathrm{min})$, and two different tool tilt angles $\left(0^{\circ}\right.$ and $\left.2^{\circ}\right)$ were used. The obtained results allowed to draw the following conclusions:

1. Process parameters such as: tool traverse speed, tool traverse speed, and tool tilt angle have an influence on the grain size of the nugget zone. Using a non-inclined tool results in a larger average grain size in the weld nugget zone $(12.8-17.3 \mu \mathrm{m})$ than when using a tool tilt angle of $2^{\circ}(9.8-15.9 \mu \mathrm{m})$. Furthermore, the average grain size decreases with an increase of a revolutionary pitch due to the increased heat input. The smallest grain size equal to $9.8 \pm 1.5 \mu \mathrm{m}$ was noted for a friction stir weld produced with a tool tilt angle $2^{\circ}$, tool traverse speed $200 \mathrm{~mm} / \mathrm{min}$, and tool rotational speed $1250 \mathrm{rpm}$.

2. The hardness measurements on the cross-sections of the friction stir welds revealed that higher hardness of the nugget zone was observed in the friction stir welds produced with an inclined tool. As the revolutionary pitch increases, the maximum hardness also increases in all the cases. The maximum hardness reached $92 \%$ of the hardness of the base material for the sample produced with the revolutionary pitch equal to 6.25 and tool tilt angle $2^{\circ}$. It was observed that with an increase of the revolutionary pitch, the radius of the nugget zone also increases.

3. Potentiodynamic studies showed that the friction stir welding process improves corrosion properties of AA6082 welds in $3.5(\mathrm{wt}) \% \mathrm{NaCl}$ solution. Using a tool tilt angle equal to $2^{\circ}$ provided lower corrosion current density in the conducted tests The best resistance $\left(16.029 \pm 0.801 \mu \mathrm{A} \mathrm{cm}^{-2}\right)$ was observed for the friction stir weld produced with the highest revolutionary pitch.

Author Contributions: Conceptualization, A.L. and M.S.; methodology, A.L.; validation, A.L., M.S. and P.C.; formal analysis, M.S., and P.C.; investigation, A.L., and D.K.; writing-original draft preparation, A.L.; writing-review and editing, P.C., and M.S.; visualization, A.L.; supervision, M.S., and P.C. All authors have read and agreed to the published version of the manuscript.

Funding: This research received no external funding.

Institutional Review Board Statement: Not applicable.

Informed Consent Statement: Not applicable.

Data Availability Statement: Not applicable.

Conflicts of Interest: The authors declare no conflict of interest. 


\section{References}

1. Thomas, W.M.W.; Norris, I.; Nicholas, E.D.; Needham, J.C.; Murch, M.G.; Temple-Smith, P.; Dawes, C.J. Friction Stir Welding Process Developments and Variant Techniques. International Patent Application No. PCT/GB92/02203 and GB Patent Application No. 9125978.8. 1991. Available online: https://www.scirp.org/(S(lz5mqp453ed\%20snp55rrgjct55))/reference/referencespapers. aspx?referenceid=2200506 (accessed on 29 December 2021).

2. Laska, A.; Szkodo, M. Manufacturing Parameters, Materials, and Welds Properties of Butt Friction Stir Welded Joints-Overview. Materials 2020, 13, 4940. [CrossRef] [PubMed]

3. Sato, Y.S.; Urata, M.; Kokawa, H. Parameters controlling microstructure and hardness during friction-stir welding of precipitationhardenable aluminum alloy 6063. Metall. Mater. Trans. A 2002, 33, 625-635. [CrossRef]

4. Ma, Z.Y.; Feng, A.H.; Chen, D.L.; Shen, J. Recent Advances in Friction Stir Welding/Processing of Aluminum Alloys: Microstructural Evolution and Mechanical Properties. Crit. Rev. Solid State Mater. Sci. 2018, 43, 269-333. [CrossRef]

5. Cavaliere, P.; Rossi, G.L.; Di Sante, R.; Moretti, M. Thermoelasticity for the evaluation of fatigue behavior of 7005/Al2O3/10p metal matrix composite sheets joined by FSW. Int. J. Fatigue 2008, 30, 198-206. [CrossRef]

6. Dursun, T.; Soutis, C. Recent developments in advanced aircraft aluminium alloys. Mater. Des. 2014, 56, 862-871. [CrossRef]

7. Hirsch, J. Aluminium in innovative light-weight car design. Mater. Trans. 2011, 52, 818-824. [CrossRef]

8. Ertuğ, B.; Kumruoğlu, C. 5083 type Al-Mg and 6082 type Al-Mg-Si alloys for ship building. Am. J. Eng. Res. 2015, 4, 146-150.

9. Ancona, A.; Daurelio, G.; De Filippis, L.A.C.; Ludovico, A.D.; Spera, A.M. $\mathrm{CO}_{2}$ Laser Welding of Aluminium Shipbuilding Industry Alloys: AA 5083, AA 5383, AA 5059, and AA 6082. In Proceedings of the XIV International Symposium on Gas Flow, Chemical Lasers, and High-Power Lasers, Wroclaw, Poland, 25-30 August 2002; pp. 577-587.

10. Thomas, W.M.; Nicholas, E.D. Friction stir welding for the transportation industries. Mater. Des. 1997, 18, 269-273. [CrossRef]

11. Kawasaki, T.; Makino, T.; Masai, K.; Ohba, H.; Ina, Y.; Ezumi, M. Application of friction stir welding to construction of railway vehicles. JSME Int. J. Ser. A Solid Mech. Mater. Eng. 2004, 47, 502-511. [CrossRef]

12. Davenport, A.J.; Kallee, S.W.; Wylde, G.J. Creating a Stir in the Rail Industry. Available online: https://www.twi-global.com/ technical-knowledge/published-papers/creating-a-stir-in-the-rail-industry-november-2001 (accessed on 29 December 2021).

13. Prabhukhot, A.R. Effect of Heat Treatment on Hardness and Corrosion Behavior of 6082-T6 Aluminium Alloy in Artificial Sea Water. Rev. Matéria 2015, 3, 544-549. [CrossRef]

14. Singh, G.; Kumar, S.; Singh, A. Influence of Current on Microstructure and Hardness of Butt Welding Aluminium AA 6082 Using GTAW Process. Int. J. Res. Mech. Eng. Technol. 2013, 3, 143-146.

15. Koprivica, A.; Bajić, D.; Šibalić, N.; Vukčević, M. Analysis of welding of aluminium alloy AA6082-T6 by TIG, MIG and FSW processes from technological and economic aspect. Mach. Technol. Mater. 2020, 5, 194-198.

16. Ericsson, M.; Sandström, R. Influence of welding speed on the fatigue of friction stir welds, and comparison with MIG and TIG. Int. J. Fatigue 2003, 25, 1379-1387. [CrossRef]

17. Hoyos, E.; Escobar, S.; De Backer, J.; Martin, J.; Palacio, M. Manufacturing concept and prototype for train component using the fsw process. J. Manuf. Mater. Process. 2021, 5, 19. [CrossRef]

18. Liu, Q.; Han, R.; Gao, Y.; Ke, L. Numerical investigation on thermo-mechanical and material flow characteristics in friction stir welding for aluminum profile joint. Int. J. Adv. Manuf. Technol. 2021, 114, 2457-2469. [CrossRef]

19. Baratzadeh, F.; Boldsaikhan, E.; Nair, R.; Burford, D.; Lankarani, H. Investigation of mechanical properties of AA6082-T6/AA6063T6 friction stir lap welds. J. Adv. Join. Process. 2020, 1, 100011. [CrossRef]

20. Varma, K.V.K.; Baig, I.; Kumar, B.V.R.R.; Ramana, M.V. Effect of friction stir welding parameters on tool geometry and metallurgical properties of AA 6082-T6 weldments at different weld zones. Mater. Today Proc. 2021, 45, 3195-3200. [CrossRef]

21. Maciel, R.; Bento, T.; Braga, D.F.O.; da Silva, L.F.M.; Moreira, P.M.G.P.; Infante, V. Fatigue properties of combined friction stir and adhesively bonded AA6082-T6 overlap joints. Fatigue Fract. Eng. Mater. Struct. 2020, 43, 2169-2180. [CrossRef]

22. Leal, R.M.; Galv, I. Recent Developments in Non-Conventional Welding of Materials. Materials 2022, 15, 171. [CrossRef]

23. Gharavi, F.; Matori, K.A.; Yunus, R.; Othman, N.K.; Fadaeifard, F. Corrosion evaluation of friction stir welded lap joints of AA6061-T6 aluminum alloy. Trans. Nonferrous Met. Soc. China Engl. Ed. 2016, 26, 684-696. [CrossRef]

24. Padovani, C.G.; Davenport, A.J.; Connolly, B.J.; Williams, S.W.; Groso, A.; Stampanoni, M.; Bellucci, F. Corrosion and Protection of friction stir welds in aerospace aluminium alloys. La Metall. Ital. 2008, 100, 29-42.

25. Ales, S.K.; Wang, L. Effects of Friction Stir Welding on Corrosion Behaviors of AA2024-T4 Aluminum Alloy. MATEC Web Conf. 2017, 109, 02003. [CrossRef]

26. Scialpi, A.; De Filippis, L.A.C.; Cavaliere, P. Influence of shoulder geometry on microstructure and mechanical properties of friction stir welded 6082 aluminium alloy. Mater. Des. 2007, 28, 1124-1129. [CrossRef]

27. Rambabu, G.; Balaji Naik, D.; Venkata Rao, C.H.; Srinivasa Rao, K.; Madhusudan Reddy, G. Optimization of friction stir welding parameters for improved corrosion resistance of AA2219 aluminum alloy joints. Def. Technol. 2015, 11, 330-337. [CrossRef]

28. Patil, H.S.; Soman, S.N. Effect of tool geometry and welding speed on mechanical properties and microstructure of friction stir welded joints of Aluminium alloys AA6082-T6. Arch. Mech. Eng. 2014, 61, 455-468. [CrossRef]

29. Naumov, A.; Rylkov, E.; Polyakov, P.; Isupov, F.; Rudskoy, A.; Aoh, J.N.; Popovich, A.; Panchenko, O. Effect of different tool probe profiles on material flow of al-mg-cu alloy joined by friction stir welding. Materials 2021, 14, 6296. [CrossRef] [PubMed]

30. Dialami, N.; Cervera, M.; Chiumenti, M. Effect of the tool tilt angle on the heat generation and the material flow in friction stir welding. Metals 2019, 9, 28. [CrossRef] 
31. Krishna, G.G.; Reddy, P.R.; Hussain, M.M. Effect of Tool Tilt Angle on Aluminum 2014 Friction Stir Welds. Glob. J. Res. Eng. 2014, $14,61-70$

32. Meshram, S.D.; Madhusudhan Reddy, G. Influence of tool tilt angle on material flow and defect generation in friction stir welding of AA2219. Def. Sci. J. 2018, 68, 512-518. [CrossRef]

33. Baghdadi, A.H.; Sajuri, Z.; Omar, M.Z.; Rajabi, A. Friction stir welding parameters: Impact of abnormal grain growth during post-weld heat treatment on mechanical properties of Al-Mg-Si welded joints. Metals 2020, 10, 1607. [CrossRef]

34. Huang, Y.; Meng, X.; Zhang, Y.; Cao, J.; Feng, J. Micro friction stir welding of ultra-thin Al-6061 sheets. J. Mater. Process. Technol. 2017, 250, 313-319. [CrossRef]

35. Huang, Y.; Meng, X.; Lv, Z.; Huang, T.; Zhang, Y.; Cao, J.; Zhou, L.; Feng, J. Microstructures and mechanical properties of micro friction stir welding ( $\mu$ FSW) of 6061-T4 aluminum alloy. J. Mater. Res. Technol. 2019, 8, 1084-1091. [CrossRef]

36. Naik, S.N.; Walley, S.M. The Hall-Petch and inverse Hall-Petch relations and the hardness of nanocrystalline metals. J. Mater. Sci. 2020, 55, 2661-2681. [CrossRef]

37. Song, Y.; Yeon, J.; Na, B. Numerical simulations of the hall-petch relationship in aluminium using gradient-enhanced plasticity model. Adv. Civ. Eng. 2019, 2019, 7356581. [CrossRef]

38. Facchini, D. Biomedical nanocrystalline metals and alloys: Structure, properties and applications. Nanomedicine Technol. Appl. 2012, 1, 36-67. [CrossRef]

39. Morozova, I.; Obrosov, A.; Naumov, A.; Królicka, A.; Golubev, I.; Bokov, D.O.; Doynov, N.; Weiß, S.; Michailov, V. Impact of impulses on microstructural evolution and mechanical performance of al-mg-si alloy joined by impulse friction stir welding. Materials 2021, 14, 347. [CrossRef]

40. Abbas, A.A.; Abdulkadhum, H.H. Effect of Shoulder-Workpiece Interference Depth on the Quality of Friction Stir Welding of AA7075-T6 Aluminium Alloy. Assoc. Arab Univ. J. Eng. Sci. 2019, 26, 150-159. [CrossRef]

41. Dawood, H.I.; Mohammed, K.S.; Rajab, M.Y. Advantages of the green solid state FSW over the conventional GMAW process. Adv. Mater. Sci. Eng. 2014, 2014, 105713. [CrossRef]

42. Pastor, A.; Svoboda, H.G. Time-evolution of Heat Affected Zone (HAZ) of Friction Stir Welds of AA7075-T651. J. Mater. Phys. Chem. 2013, 1, 58-64. [CrossRef]

43. Rodríguez, A.; Calleja, A.; López de Lacalle, L.N.; Pereira, O.; González, H.; Urbikain, G.; Laye, J. Burnishing of FSWAluminum Al-Cu-Li components. Metals 2019, 9, 260. [CrossRef]

44. Wahid, M.A.; Khan, Z.A.; Siddiquee, A.N. Review on underwater friction stir welding: A variant of friction stir welding with great potential of improving joint properties. Trans. Nonferrous Met. Soc. China Engl. Ed. 2018, 28, 193-219. [CrossRef]

45. Cavaliere, P.; Squillace, A.; Panella, F. Effect of welding parameters on mechanical and microstructural properties of AA6082 joints produced by friction stir welding. J. Mater. Process. Technol. 2008, 200, 364-372. [CrossRef]

46. Ahmed, M.M.Z.; Abdelazem, K.A.; El-Sayed Seleman, M.M.; Alzahrani, B.; Touileb, K.; Jouini, N.; El-Batanony, I.G.; Abd El-Aziz, H.M. Friction stir welding of 2205 duplex stainless steel: Feasibility of butt joint groove filling in comparison to gas tungsten arc welding. Materials 2021, 14, 4597. [CrossRef] [PubMed]

47. Krasnowski, K.; Sedek, P.; Łomozik, M.; Pietras, A. Impact of selected FSW process parameters on mechanical properties of 6082-T6 aluminium alloy butt joints. Arch. Metall. Mater. 2011, 56, 965-973. [CrossRef]

48. Aldanondo, E.; Vivas, J.; Alvarez, P.; Hurtado, I. Effect of Tool Geometry and Welding Parameters on Friction Stir Welded Lap Joint Formation with AA2099-T83 and AA2060-T8E30 Aluminium Alloys. Metals 2020, 10, 872. [CrossRef]

49. Qin, H.L.; Zhang, H.; Sun, D.T.; Zhuang, Q.Y. Corrosion behavior of the friction-stir-welded joints of 2A14-T6 aluminum alloy. Int. J. Miner. Metall. Mater. 2015, 22, 627-638. [CrossRef]

50. Zucchi, F.; Trabanelli, G.; Grassi, V. Pitting and stress corrosion cracking resistance of friction stir welded AA 5083. Werkstoffe und Korrosion 2001, 52, 853-859. [CrossRef]

51. Wang, H.F.; Wang, J.L.; Song, W.W.; Zuo, D.W.; Shao, D.L. Analysis on the corrosion performance of friction stir welding joint of 7022 aluminum alloy. Int. J. Electrochem. Sci. 2016, 11, 6933-6942. [CrossRef]

52. Monetta, T.; Montuori, M.; Squillace, A.; Bellucci, F. The Effect of Heat Treatment and Welding Parameters on the Corrosion Behaviour of a Friction Stir Welded 6056 Aluminium Alloy. Adv. Mater. Res. 2008, 38, 285-297. [CrossRef]

53. Ralston, K.D.; Fabijanic, D.; Birbilis, N. Effect of grain size on corrosion of high purity aluminium. Electrochim. Acta 2011, 56, 1729-1736. [CrossRef]

54. Song, D.; Ma, A.; Jiang, J.; Lin, P.; Yang, D. Corrosion behavior of ultra-fine grained industrial pure Al fabricated by ECAP. Trans. Nonferrous Met. Soc. China Engl. Ed. 2009, 19, 1065-1070. [CrossRef] 